\title{
FREEDOM AND SOLIDARITY: SOME REMARKS IN LIGHT OF THE CONTEMPORARY RECEPTION OF HEGEL
}

\author{
LIBERDADE E SOLIDARIEDADE: ALGUMAS OBSERVAÇÕES À LUZ \\ DA RECEPÇÃO CONTEMPORÂNEA DE HEGEL
}

FILIPE CAMPELLO ${ }^{1}$

(UFPE, Brazil)

\begin{abstract}
This paper has in view the relationship between emotions and justice which has been increasingly found in the literature in the past years. The core idea we find in this debate is that the descriptive validity of a social theory depends on the analyses of the constitutive role of emotions on social spheres. On the other hand, I want to suggest that Hegel can contribute towards a "normative" potential of those analyses through the approach of the formative character of institutions, oriented by what can be understood as the institutional mediation of individual freedom through the idea of socially inclusive, "decentralized will". In this paper, I will focus on the discussion of these ideas regarding the civil society, where I develop my argument in three short steps. Firstly, I will briefly suggest in what sense Hegel could help us in discussing the relation between ethical life ("Sittlichkeit") and affective relations. In a second step I will point out a specific emotional component in the sphere of civil society, namely, the relationship between passions and interests. Finally, I will connect this idea to a peculiarity based on Hegel's model of solidarity - as we find in the work of Axel Honneth - related to the concept of the formation of Will ("Willensbildung"), arguing that solidarity depends not only on rational guided actions, but also in how far an institutional framework enables a volitional dimension that is justified, on one hand, by the satisfaction of individual needs and, on the other, by the sentiment of cooperation.
\end{abstract}

Keywords: Emotions. Theories of justice. Hegel. Ethical life. Social justice.

\section{Why Hegel?}

In the last years, the acknowledgment of the limitations of strictly rational-based models led, in different fields, to increasing debate on the role of emotions and affective components in the analyses of decision making, preferences or dynamics of social movements ${ }^{2}$. Even if one can talk here of a "renaissance" of these subjects, almost every philosophical tradition was balanced between the discussions of reason and emotion, the prevalence of one or the other, and the implications of these tensions in politics. If we take the rich variety in modern philosophy, these discussions are easily associated with Machiavelli, Bacon, Hobbes, Spinoza or Hume. At first glance, the name of Hegel, however, seems to be here quite odd. Indeed, many interpretations of his philosophy have neglected the role played by passions and emotions insisting instead on a rather obscure concept of "rational". Conversely, I have 
suggested that emotions play a fundamental role in Hegel's theory of ethical life (Sittlichkeit), where an institutional framework should have in view the power of the emotional - or what we can call "affective" - dimension in ethical life ${ }^{3}$.

The set of questions that guide my argument comprehends the revision of a theory of rationality through a weak naturalism wherein the social spaces are orientated not only by communicative rational standards, but also by emotive and cognitive inclusion of plural reasons. In this way, I suggest that Hegel can offer not only a descriptive account of the affective content in ethical life, but also a kind of normative aspect of emotion and its specific reasons, that are not reducible to an orientation towards a universal or abstract regulative idea, but rather, permeated by reasons for action whose logic involves an intrinsically emotive dimension. In fact, Hegel's critique of the formal morality was motivated by the role that passions play in human agency, where an external universal moral law would not be able to endorse all aspects of a normative theory. Since Hegel's Frankfurt writings, the core of his critique on Kant was that the external submission of the laws of the positive character of religion was, through the Kantian morality, only internalized, so that there remains what Hegel identifies as alienation and submission by a slave to a master, represented in this case as an internal moral law (Hegel, 1971, p.301). The reconciliation with the subjective dimension - where the subject expresses himself not through submission, but as autonomous Hegel saw the embodiment of a moral theory with the nature of subjectivity: the role played by drives, desires, passions. These dimensions Hegel - in reference to Christian tradition (mainly in st. Paul) - called the fulfillment ("pleroma") of the law, both of a positive law as well as the moral one (Hegel, 1971, p.326ss).

Still in his time in Frankfurt and under the influence of the Romantic Movement, mainly from Schiller and Hölderlin, Hegel saw the paradigmatic case of this fulfillment, a kind of reconciliation of morality and nature, in love (Hegel, 1971, p.242ss). In this view, love has an emotive character that at same time expresses a particular concept of duties, not only an obligation in the sense of a juridical or moral law. Already the core idea established is that one is not free while submitted to any kind of law, either external (in the case of the juridical) or internal (in the case of morality), but only when the very content of one's will is freedom itself. This idea encapsulates the first intuitions of Hegel's theory of ethical life, with the same logic of "be one self in the other", the conciliation of nature and morality in a more organic and lively concept of "Sittlichkeit" that Hegel developed later in his Philosophy of Right. 
This development was guided by the discussion on the transition from a natural and primary level - Hegel's concept of arbitrariness ("Willkür") - to the free will. In this picture the link between social dimension and human nature - expressed in the concept of "second nature" - is in Hegel intrinsically connected to a theory of freedom: Freedom means a selfrestriction of an empty arbitrariness in a social context that makes it possible to give it content, a shape, a determination. In doing so, Hegel contested a "negative" concept of freedom by this conceptual scheme where the content of freedom is fundamental for the freedom itself. So we find in different texts from Hegel a kind of regulative idea to be found in the link between freedom and desires, where a self-limitation of an egocentric arbitrariness gives way to a "rational" will. "Rational" means therefore a will that has freedom as its content: the free will is only free when wants itself to be free. It is at this point in his Philosophy of Right that Hegel sees as a paradigmatic case of a "concrete" freedom - as in his Frankfurt writings - in the intersubjective relation of friendship and love:

[The] concrete freedom we already have in the form of sentiment, as in friendship and love. Here a man is not one-sided, but limits himself willingly in reference to another, and yet in this limitation knows himself as himself. In this determination he does not feel himself determined, but in the contemplation of the other as another has the feeling of himself. Freedom also lies neither in indeterminateness nor in determinateness, but in both. The wilful man has a will which limits itself wholly to a particular object, and if he has not this will, be supposes himself not to be free. But the will is not bound to a particular object, but must go further, for the nature of the will is not to be one-sided and confined. Free will consists in willing a definite object, but in so doing to be by itself and to return again into the universal. (Hegel, 1991,§7, Addition)

Whereas love was remained since Hegel's Frankfurt writings the paradigmatic case of this intersubjective and affective content of freedom, a new tension emerges when Hegel influenced by economic theories such as those of Adam Smith - realizes that this conceptual framework was quite impotent to analyze more complex relations in civil society and state, where a kind of affective component was more fragile and completely different than in the cases of primary relations ${ }^{4}$. Hegel saw the persistence of these kinds of (only primarily affective) bonds in the other spheres of ethical life as problematic, insofar as it led to patriarchal political forms. So a central aspect presented by the young Hegel is how the affective content of love, that at same time is not reducible to a kind of sentimentalism, 
involves duties and expectation - a relation between affect and agency - can be also founded in the social sphere.

If in this way Hegel insists on an important and clear distinction between the relations in family, civil society and state, he, however, does not deny a volitional content in these other spheres, emphasizing the role of passions in both spheres. I would like to suggest that, as in the process of subjectivation and in his primary moments in the family, Hegel saw the other spheres of ethical life in the market and the civic participation in the state as an actualization of subjectivity through a decentralized perspective, in consonance with the same concept of free will and a formation of affects to an inclusive dimension. In this sense, concerning the sphere of civil society, interpretations of Hegel have discussed two main lines, one connected with different issues on the public sphere (which Hegel in his time discussed rather regarding the sphere of state) and another linked to Hegel's political economy ${ }^{5}$. Whereas, regarding the first, an emotional content can be found in the oft discussed role of passions in historical transformations and in the conflictive character of the public sphere besides a rational character, in Hegel's discussion on market and economy this emotional dimension - as I see it - can be found in the complex relationship between passions and interests $^{6}$. This point I shall explore more closely in following discussion.

\section{Passions and Interests}

In an important study in the history of economic ideas entitled The Passions and the Interests, Albert Hirschman reconstructs the transformation of the arguments used to support the rise of capitalism (Hirschman, 1997). The main idea is that the best way found to legitimize it was neither a repression nor a harness of passions, but rather their reciprocal neutralization, what he calls "the principle of the countervailing passions" (Hirschman, 1997, p. 20). Based in different nuances from Machiavelli through Bacon, Spinoza and Hume, this principle claims that only a passion is strong enough to contradict another passion. Hirschman argues that it was this idea that came to be used with the rising centrality of the concept of interest, which was not a concept opposed to passion but rather a "countervailing passion" impregnated with a passionate or emotional content. In this internal conceptual change, interest was saw as a kind of "positive" passion - the pleasure found in obtaining money - that at the same time was legitimized as a necessary passion against other passions considered as "negative". On the other hand, this relation, Hirschman argues, grounded some strategic 
motives and here interests should appear to be as opposed to passions: whereas passions broadly understood were seen as violent and unpredictable, interests were associated with predictability, constancy and calm - "money-making as a calm passion" (Hirschman, 1997, p. 63ss.) -, which should justify the preference for it.

In the arguments used the support to the rise of the capitalism, however, it is not clear if interests should have a decentralized, inclusive perspective in a social dimension. Rather, since the beginning the internal transformation of the discourse on passions was used fundamentally as legitimization only of self-interests. Even if for instance Adam Smith wanted to break with some vertical relation, as in the feudal societies, and sees the market now as a possibility of equal autonomy and space of freedom, his solution proposed with selfregulation of markets tried to put together the realization of self-interests inside a theory of free market. This concept, however, was based on the assumption that given a space where the individuals could act more freely, these autonomous and free agents in the market could be compatible with social progress and the benefit of all society.

Curiously, as Hirschman observes but without keeping the consequences of it, Smith did not discuss the difference between passions and interests. A possible interpretation is that the consequences of his theory of moral sentiments was so intrinsically connected to his economic theory, that what moves on this self-interest was seen as impregnated with emotional content. Here emerges the so-called "Adam Smith problem": the broadly discussed issue of Smith's theory of moral sentiments and his economic theory as ambiguous or coherent, or, in other words, if there is or is not a tension between rational calculation actors guided by self-interests and a social mediated relation ${ }^{7}$.

As I see it, the argument of Adam Smith is partially plausible in the sense of having in view the emotions involved in self-interest and not only in the sense of a previous rationality but at the same time through the sentiments that move it. It is here that Smith's thesis is more promising for our reconstruction. In fact, it is meaningful that his argument can be based on a theory of moral sentiments: even with the emphasis on self-interests, also in the market should be presupposed a kind of inclusive sentiment that could ensure the success of contractual relations. So Smith sees for example "trust" in base of that relation guided from self-interest. The dichotomy between interests and passion is contested here in a particular way: interest seems to be linked to the idea of a rational calculation, but one that for its part depends on a previously emotive content. In that way, at same time that Smith sustains the concept of self-interest as guide for economic agency, he seems to indicate another thesis: that a previous frame of moral sentiments could secure the success of actions based on interests. 
So the assumption that could be hereby shared with Smith is that of a more realistic approach, which the agents in the economic relations effectively behave for self-interest, which itself depends upon a passionate content. Precisely because of this fact it is central to stress the perspective of a reframing of these passions, in which his theory of moral sentiments could give a first light.

The reconstruction of Hirschman does not highlight the name of Hegel, but this is not by chance. Even if - as I suggest - Hegel has in his theory of ethical life a strong attention to passions and emotions, his kind of social ontology was fundamentally different from the tradition that Hirschman describes. Exactly at this point Hegel can be helpful in giving a complementary position to this relation between passions and interests: at the same time that he shares with this tradition that emotional content and a similar concept of human nature, the picture that he suggests has a fundamentally both intersubjective and normative approach. The question here is not only reducible to the passionate content of interest, but also tries to elucidate an institutional framework that having in account this social mediated formative process of the will.

If, at first, the principle of countervailing passions shows that interest is not understood as a pure rational strategic action, it should be shown, in a second step, what the differential point that Hegel's argument suggests is; with the thesis that passions are constitutive from interest, one should then look not only at a rational level, but at the working out of passions: interests related with a formation of passions in a decentralized perspective, as was pointed out concerning Hegel's idea of free will.

\section{Emotions and "institutionalized solidarity"}

With this background I come to my last step. In the work of different authors, we find the specific emotional and affective content related to the market or broadly social relations expressed in the concept of solidarity. So in the tradition of critical theory, this concept was mainly used by Jürgen Habermas ${ }^{8}$ and, more recently, Axel Honneth ${ }^{9}$. In contrast to Habermas, Honneth - referring to Durkheim's concept of “organic solidarity" - understands solidarity not as a formal normative principle, but rather as a result of recognizing the activity of other citizens as a contribution for a group that has shared goals. This first step from this Durkheim picture is therefore different from a "universalist" concept of solidarity. For Honneth this notion is spelt out with the idea that a solidary appreciation of the activities of 
others includes a certain emotional component: one feels affected by the fact that the other is acting in a way which helps our commonly shared goals to become real.

Here, the Kantian solution of dignity based on the fact that we are rational beings seems - at first glance - to be connected, in this emotive dimension, to something like a sentiment of humanity that can be shared. In Honneth's idea of solidarity, however, shared goals are needed and therefore it would be possible to extend this idea to something like "humanity" only insofar some goals can be seen as shared, or if there is here a real sentiment of cooperation. Different from respect or some kind of moral rule, one could see in this presupposition a moral content linked rather to an affective tone as a shared sentiment and he defends that the market can be a sphere of social freedom, but only insofar as previously there is a non-contractual relation. Claiming for a "solidary consciousness" (2011, p. 329), Honneth writes:

In Hegel's terminology it is possible to express the idea that a coordination of simple calculation of individual preferences - which is proceeded in the sphere of market - can only be successful if the involved subjects are recognized not only as juridical contract partners, but also morally and ethically [sittlich] as members of a cooperative community. (Honneth, 2011, p. 329) ${ }^{10}$

Honneth says that both Hegel and Durkheim have in view that the effectuation of the contractual sphere in the market depends on previous guarantees based on a solidary consciousness. The emphasis here is on a non-contractual dimension, where could be emphasized an affective content, what Honneth sees as solidarity in Durkheim, trustful relation in Smith, or "honor" in Hegel. In this way, this approach on solidarity grounded in shared interests and goals can help to answer the question of how solidarity can have that content that Hegel had in mind, namely the question of what can lead to this sentiment of cooperation. As we have briefly seen, Hegel was, from the beginning, skeptical about the Kantian solution of an obligation to a moral law guided by the respect to rational beings, so that these inclusive interests could not be found only by force of a moral argument; this not only because of that submission and limitation to an internal moral law, but also due to - as we saw in the second step of the argument - the fictitious differentiation between passions and interests (as something rational opposed to passions), so that the very level of passions become central in this picture. 
The idea we find throughout Hegel's works (not only in his Philosophy of right, but also in his Encyclopedia) is that the concept of free will is not predeterminate, but a result of a complex, social articulated working out of inclinations, drives, desires ${ }^{11}$. In this way, neither a juridical nor a moral law, but rather the institutions express the most adequate locus for the mediation of free will. In this way, Hegel develops the spaces of realization of freedom in his theory of ethical life ("Sittlichkeit") as a theory of institutions - as the "kingdom of actualized freedom" (Hegel, 1991, §4). In this sense, a normative approach - understood not as an external, formally/based principle but rather, as immanent normative critique - concerns the question how far a social, institution mediated framework makes possible the realization of individual freedom as expression of social embodied relations ${ }^{12}$.

Hegel's own solution to give a normative and critical inflection to this individualistic interest in the emerging capitalist society was in his ground concept of "Bildung" (formation): the transition from arbitrariness to free will which, in the sphere of market, appears as a working out of interests. In fact, in consonance of the picture of a learning process inside each sphere of ethical life, Hegel's intuition of the formation specific to civil society indicates that interest is the specific component relating to satisfaction of those needs which refer to the market $^{13}$. In Hegel this is mainly one grounded on the constitutive formation through institutionalized forms, like in his idea of "corporation" and through work and cooperation. He also shares that individuals can be guided by self-interests, but instead of a kind of invisible hand, it depends on a reorientation of action and purposes - on the content of will itself, not as a secondary consequence, but as a substantial characteristic of the will.

However, Hegel saw, mainly regarding the civil society and its economic relations, the contingence of such individual agency, while depending only on a solidary consciousness, to avoiding poverty and promoting social justice. In fact, whereas, on one side of this process, Hegel indicates emotive dimensions as "emotion" and "love" 14 , on the other side the point in view of his approach should not reduce the concept of solidarity to a kind of benevolence or pity, which would be a misunderstanding and would in no way substitute the grounded importance to have rights secured trough moral grounded institutional framework ${ }^{15}$. Rather, a "particularity of emotion" should be connected with the "public conditions", as he writes in his Philosophy of Right: 
The contingent character of almsgiving and charitable donations (e.g. for burning lamps before the images of saints, etc.) is supplemented by public poorhouses, hospitals, streetlighting, etc. Charity still retains enough scope for action, and it is mistaken if it seeks to restrict the alleviation of want to the particularity of emotion and the contingency of its own disposition and knowledge [Kenntnis], and if it feels injured and offended by universal rulings and precepts of an obligatory kind. On the contrary, public conditions should be regarded as all the more perfect the less there is left for the individual to do by himself [für sich] in the light of his own particular opinion (as compared with what is arranged in a universal manner). (Hegel, 1991, §242, Note)

Therefore, Hegel concludes, the achievement of social justice would be only possible through the "payment of taxes" (Hegel, 1991, §184, Addition). At the same time, the very consciousness of the role of taxes is already dependent on a social decentered perspective, that is not opposed to the realization of particular interests, but neither is independent of social fairness. So puts Hegel:

most people regard the payment of taxes, for example, as an infringement of their particularity, as a hostile element prejudicial to their own ends; but however true this may appear, the particularity of their own ends cannot be satisfied without the universal, and a country in which no taxes were paid could scarcely distinguish itself in strengthening its particular interests [Besonderheit]. (Hegel, 1991, §184, Addition)

The emphasis, therefore, on an emotional content cannot deny the fundamental moral progress guaranteed - as a normative reconstruction can show - in forms of institutions and rights: an institutionalized solidarity. The point is rather to identify a model not only for how an ideal model of solidarity should be, but also to try to better understand what is going on in social transformations. Regarding its normative character - as was proposed with Hegel's idea of "fulfillment" - it is the result of a way of putting out some expression of subjects, not only as a submission neither to external or moral law, but rather where they can experience themselves in their action. In this idea of "Bildung" the laws are, on the contrary, an expression of what is experienced; not self-referenced and limited as in its primary egocentric moment, but as a result of complex and plural forms of freedom founded and elaborated in the ethical life. 


\section{Notes:}

${ }^{1}$ Filipe Campello is Professor of Philosophy at the Federal University of Pernambuco (Recife, Pernambuco, Brazil). He obtained, under the supervision of Axel Honneth and Christoph Menke, the doctoral degree of Philosophy at the Goethe-University in Frankfurt am Main, with a scholarship from the German Academic Exchange Service (DAAD). His publications include: Axel Honneth y la renovación de la Teoría Critica (In: Diálogos de pensamiento critico); Love, Society and Agape: An Interview with Axel Honneth, European Journal of Social Theory (with Gennaro Iorio); and Die Natur der Sittlichkeit: Grundlagen einer Theorie der Institutionen nach Hegel, Transcript Verlag (in preparation). E-mail: filipebcampello@gmail.com.

2 See for example Hall 2005; Hoggett/Thompson 2012; Kingston/Ferry (eds.) 2008; Krause 2008; Walzer 2006; Nussbaum 2013 and Prinz 2008.

3 See Campello (in preparation). With the concept of "affective" content we have in view a kind of both naturalistic and intersubjective component. For this broadly issue, see Rorty 1980, Hartmann 2010 and Demmerling/Landweer 2007.

\footnotetext{
${ }^{4}$ See Honneth 1994, p. 172 ss. and Honneth 2011, p. 317 ss.

${ }^{5}$ See Coehen/Arato 1999, Pelczynski 1984 and Herzog 2013.

${ }^{6}$ See for discussion: Frank 1988, Solomon 2003, Blackburn 1998.

${ }^{7}$ For this issue, see Herzog 2013 and Honneth 2011, p. 317 ff.

${ }^{8}$ For a detailed approach, see Pensky, 2008.

${ }^{9}$ See Honneth 1994, 2001.

${ }^{10}$ The translations from Honneth are my own.

${ }^{11}$ See Honneth 2001, p. 21 ss and Campello (in preparation).

${ }^{12}$ For this issue, see also Honneth 2011.
}

13 "Education [Bildung], in its absolute determination, is therefore liberation and work towards a higher liberation; it is the absolute transition to the infinitely subjective substantiality of ethical life, which is no longer immediate and natural, but spiritual and at the same time raised to the shape of universality. Within the subject, this liberation is the hard work of opposing mere subjectivity of conduct, of opposing the immediacy of desire as well as the subjective vanity of feeling [Empfindung] and the arbitrariness of caprice. The fact that it is such hard work accounts for some of the disfavour which it incurs. But it is through this work of education that the subjective will attains objectivity even within itself, that objectivity in which alone it is for its part worthy and capable of being the actuality of the Idea. - Furthermore, this form of universality to which particularity has worked its way upwards and cultivated [herausgebildet] itself, i.e. the form of the understanding, ensures at the same time that particularity becomes the genuine being-for-itself of individuality [Einzelheit]; and, since it is from particularity that universality receives both the content which fills it and its infinite self-determination, particularity is itself present in ethical life as free subjectivity which has infinite being-for- itself. This is the level at which it becomes plain that education is an immanent moment of the absolute, and that it has infinite value". (Hegel, 1991, §187, Note)

14 "The subjective aspect of poverty, and in general of every kind of want to which all individuals are exposed, even in their natural environment, also requires subjective help, both with regard to the particular circumstances and with regard to emotion and love" (Hegel, 1991, §242). 
15 "But since this help, both in itself [für sich] and in its effects, is dependent on contingency, society endeavours to make it less necessary by identifying the universal aspects of want and taking steps to remedy them" (Hegel, $1991, \S 242)$. 


\section{References}

Blackburn, Simon. 1998. Ruling passions. A theory of practical reasoning. Oxford / New York: Clarendon Press.

Campello, Filipe (in preparation): Die Natur der Sittlichkeit: Grundlagen einer Theorie der Institutionen nach Hegel. Bielefeld: Transcript Verlag.

Campello, Filipe; Iorio, Gennaro. 2013. Love, Society and Agape: An Interview with Axel Honneth. European Journal of Social Theory, 16(2), 246-258.

Cohen, Jean L.; Arato, Andrew. 1999. Civil Society and Political Theory. Cambridge: MIT Press.

Demmerling, Christoph; Landweer, Hilge. 2007. Philosophie der Gefühle: von Achtung bis Zorn. Stuttgart [u.a.]: Metzler.

Frank, Robert H. 1988. Passions within reason. The strategic role of the emotions. New York: Norton.

Hall, Cheryl 2005. The Trouble With Passion: Political Theory Beyond the Reign of Reason, London: Routledge.

Hartmann, Martin 2010. Gefühle: Wie die Wissenschaften sie erklären. Frankfurt a. M.: Campus.

Hegel, G.W.F. 1971. Der Geist des Christentums und sein Schicksal. Frankfurt a. M.: Suhrkamp.

1971b. Grundlinien der Rechtsphilosophie. Frankfurt a. M.: Suhrkamp.

1991. Elements of the Philosophy of Right, translated by H. B. Nisbet, Cambridge: Cambridge University Press.

Herzog, Lisa 2013. Inventing the market. Smith, Hegel, and political theory. Oxford: Oxford University Press.

Hirschman, Albert O. 1977. The Passions and the Interests: Political arguments for capitalism before its triumph. Princeton: Princeton University Press.

Hoggett, Paul; Thompson, Simon 2012. Politics and the emotions. The affective turn in contemporary political studies. New York: Continuum.

Honneth, Axel. 1994. Kampf um Anerkennung. Zur moralischen Grammatik sozialer Konflikte: Mit einem neuen Nachwort. Frankfurt a. M.: Suhrkamp. 
Suhrkamp.

2011. Das Recht der Freiheit. Grundriß einer demokratischen Sittlichkeit. Berlin:

Kingston, Rebecca, Ferry, Leonard (eds.). 2008. Bringing the Passions Back In: The Emotions in Political Philosophy. Vancouver: UBC Press.

Krause, Sharon. 2008. Civil Passions: Moral Sentiment and Democratic Deliberation, Princeton: Princeton University Press.

Nussbaum, Martha C. 2001. Upheavals of Thought. The Intelligence of Emotions. Cambridge/New York: Cambridge University Press.

2013. Political Emotions: Why Love Matters for Justice. Cambridge: Harvard University Press.

Pelczynski, Z. A. (ed.). 1984. The State and Civil Society. Studies in Hegel's political Philosophy. Cambridge/ New York: Cambridge University Press.

Pensky, Max. 2008. The ends of solidarity. Discourse theory in ethics and politics. Albany / NY: State Univ. of New York Press.

Prinz, Jesse. 2008. The Emotional Construction of Morals. Oxford: Oxford University Press.

Rorty, Amélie (ed.). 1980. Explaining Emotions. Berkeley: University of California Press.

Solomon, Robert C. 2003. Not Passion's Slave. Emotions and Choice. Oxford / New York: Oxford University Press.

Walzer, Michael. 2006. Politics and Passion: Toward a More Egalitarian Liberalism, New Haven: Yale University Press. 